九州大学学術情報リポジトリ

Kyushu University Institutional Repository

\title{
Energy-Harvesting-Based Wireless Sensor Nodes for Inaccessible Environments
}

Dr. Kawsar Ali

Power Electronics Group Department of Engineering Science, University of 0xford : PostDoctoral Research Associate

https://doi.org/10.5109/4738549

出版情報: Proceedings of International Exchange and Innovation Conference on Engineering \& Sciences (IEICES).7，pp.34-35，2021-10-21. 九州大学大学院総合理工学府 バージョン：

権利関係: 


\section{Keynote Speaker}

\section{Dr. Kawsar Ali}

Post-Doctoral Research Associate, Power Electronics Group

Department of Engineering Science, University of Oxford

Email: kawsar.ali@eng.ox.ac.uk

\section{Short Biography}

Kawsar Ali received the B. Tech. degree from National Institute of Technology (NIT), Durgapur, India in 2011 and the PhD degree from National University of Singapore (NUS) in 2018, both in electrical engineering. His doctoral research was on high performance three-phase AC/DC power electronic converters for data centre and telecom loads. From 2011 to 2014, he was with the Indian Oil Corporation Limited as an Operations Officer. He joined the Engineering Science Department of the University of Oxford, UK in 2018 as a postdoctoral research associate, where he works on the power electronics design of ultra-low power energy harvesting systems, resonant power conversion, and application of wide-bandgap devices. 


\title{
Energy-Harvesting-Based Wireless Sensor Nodes for Inaccessible Environments
}

\begin{abstract}
An energy harvester not facing the incident energy properly will have poor or zero yield. The success of a radio communication depends on the clear line of sight between the transmitter and the receiver. Therefore, the successful operation of a traditional EnergyHarvesting-Based Wireless Sensor Node (WSN) is critically dependent on the placement and orientation of its harvester and antenna. But deploying such WSNs in challenging environments (e.g., active volcanos, nuclear waste disposal sites, defence applications) often means the user does not have precise control over their placement and orientation. Significant cost (e.g., the use of special-purpose robots or drones) is incurred to ensure proper placement and orientation of traditional WSNs in such cases. This presentation introduces an Oxford-made smart WSN device whose operation does not depend on its placement and orientation. The proposed WSN unit is a cube-shaped device, each side of which is a complete wireless sensor module, sharing a common energy storage and a common communication bus with the other faces. An energy-efficient algorithm is designed based on the concepts of 'strongest energy face' and 'strongest radio face'. The proposed algorithm facilitates energy and information sharing among the faces of the cube with the common goal of harvesting the maximum possible energy from all sides, aggregating the energy on the shared energy bus, and then using the strongest radio face to transmit the sensed signal to the base station. The concept is verified in a $50 \mathrm{~cm}^{3}$ laboratory prototype built with off-the-shelf components. The experimental results show that the device successfully transmits the sensed data even in the worst case where only one face, which may not be the transmitting face, is harvesting energy.
\end{abstract}

